University of Nebraska - Lincoln

DigitalCommons@University of Nebraska - Lincoln

1940

\title{
CHANGES IN TRUE-PRAIRIE VEGETATION DURING DROUGHT AS DETERMINED BY LIST QUADRATS
}

\author{
J. E. Weaver \\ University of Nebraska-Lincoln \\ Joseph H. Robertson \\ University of Nebraska-Lincoln \\ Robert L. Fowler \\ University of Nebraska-Lincoln
}

Follow this and additional works at: https://digitalcommons.unl.edu/agronweaver

Part of the Terrestrial and Aquatic Ecology Commons

Weaver, J. E.; Robertson, Joseph H.; and Fowler, Robert L., "CHANGES IN TRUE-PRAIRIE VEGETATION DURING DROUGHT AS DETERMINED BY LIST QUADRATS" (1940). Papers of John E. Weaver (1884-1956). 12.

https://digitalcommons.unl.edu/agronweaver/12

This Article is brought to you for free and open access by the Agronomy and Horticulture Department at DigitalCommons@University of Nebraska - Lincoln. It has been accepted for inclusion in Papers of John E. Weaver (1884-1956) by an authorized administrator of DigitalCommons@University of Nebraska - Lincoln. 


\title{
CHANGES IN TRUE-PRAIRIE VEGETATION DURING DROUGHT AS DETERMINED BY LIST QUADRATS
}

\author{
J. E. Weaver, Joseph H. Robertson, and Robert L. Fowler \\ University of Nebraska, Lincoln
}

The drought of 1934 was not only the most severe on record for the true-prairie association but was also of the earliest inception. On June 8, Kincer ('34) stated that "pastures are the poorest ever known, and the hay crop will be extremely short, regardless of future weather." The stress increased as the summer advanced. Stoddart ('35) took advantage of these conditions to investigate the relation of osmotic pressure and water content of prairie plants to environmental factors in the vicinity of Lincoln, Nebraska. Simultaneously, Nedrow ('37) was conducting trenching experiments in his study of the efficiency of absorption at different depths by roots of prairie plants. Three of the four prairie grasses studied delayed their development in direct proportion to the depth at which they were watered. Studies of this drought were extended and correlated by Weaver, Stoddart, and Noll ('35), and by Weaver and Albertson ('36). The latter work extended into the mixed prairie where permanent quadrats had been established before the drought. These workers described in detail the drought injury of 1934 and the increase of certain native grasses, native forbs, and ruderals in 1935.

Following the nearly normal precipitation of 1935, the year 1936 was even hotter and drier than 1934. The two following years were likewise drier than normal as was also 1939 at the time of completion of the present study. Rainfall for the early parts of 1938 and 1939, however, was approximately normal. Weather during May contrasted sharply for the two years. That of 1938 was cool and very wet, while in 1939 May was dry and temperatures were far above normal. Prairie soil near Lincoln had 2 per cent or more available moisture at all depths during the growing season of 1938, until late July when the upper 6 inches dried below this point. Sampling in 1939 showed that moisture became unavailable in the first 6 inches as early as May at three stations and at only one was the soil again wet to as much as 20 per cent available moisture in the growing season. The southwesternmost station (Montrose, Kansas) contained no available moisture between the one- and sixfoot levels from May to August, inclusive (Weaver and Albertson, '40). Fortunately, a record of the normal condition of the true-prairie association was made just prior to the drought (Weaver and Fitzpatrick, '34).

In 1936, nine prairies which had been described by Weaver and Albertson ('36) were selected for more intensive study of the behavior of true-prairie vegetation following drought. These prairies were within a radius of 110 miles to the south and west of Lincoln. One hundred permanent sample plots, usually one square square meter in area, were located so as to obtain replicate samples of the most important species on each prairie. A census of these was made in 1936 and 1937. The analysis with supplementary studies is published elsewhere (Robertson, '39).

Because of the increasing weediness of the easternmost prairies, portions of several were placed under cultivation in 1938 or 1939 , so that only 75 of the sample plots remained. A census of these was taken each summer, and an interpretation of the data is presented here in comparison with that obtained from the same plots in 1936 and 1937.

These 75 plots contained an aggregate of 110 species which included 28 perennial grasses, 40 perennial native forbs, 11 annual native forbs, 1 annual native grass, 
and 30 ruderals, nearly all of which were annuals. Determinations near Lincoln before and after the drought of 1934 showed a 36 per cent reduction in basal cover on the upland (Weaver and Albertson, '36). Estimates for the area as a whole vary from 40 to 60 per cent reduction. Fluctuations in cover after 1936 are shown by variations in the number of square decimeter units devoid of vegetation each season. In 1936, there were 3.2 bare units per plot. This was followed by an increase of 25.1 per cent in 1937, an 18.1 per cent decrease in 1938 , and a 24.1 per. cent increase in 1939 , or a net increase of 27.2 per cent since 1936 . Certain species were found to be quite stable. For example, from 1936 to 1939 Amorpha canescens caused only 2 bared units by its death while invading four, although it occurred in 31 of the sample plots. In contrast, Agropyron smithii invaded 163 bare units during the threeyear period while creating only 61 new ones, and Andropogon scoparius left 19 units bare while invading 8 . The relative stability of the most important species and their increase or decrease in 1939 in percentage of the number of stems present in 1936 are given in table 1.

For purposes of comparison, the 110 species were separated into three groups: $(a)$ perennial grasses, $(b)$ perennial native forbs, and (c) annuals-including ruderals, native grasses, and non-grasses.

Perennial grasses in 1938 more than recovered their losses of 1937 and by 1939 this group had twice as many stems as in 1936 (fig. 1). This occurred notwithstanding a general reduction of 20 per cent in 1937 and further small decreases of Andropogon scoparius and a few minor species in 1938. The chief percentage gains from 1936 to 1939 were made by Sporobolus cryptandrus ( 480 per cent), Bouteloua gracilis (328 per cent), B. curtipendula (223 per cent), Sporobolus asper (146 per cent), and Carex spp. (119 per cent). A similar ranking in 1938 placed Panicum wilcoxianum, Buchloe dactyloides, and Agropy-
TABLE 1. Percentage change in abundance and relative stability of important species as shown by the number of bare square decimeter units under observation created by death or invaded from 1936 to 1939

\begin{tabular}{|c|c|c|c|}
\hline & $\begin{array}{c}\text { Bare } \\
\text { units } \\
\text { created }\end{array}$ & $\begin{array}{c}\text { Bare } \\
\text { units } \\
\text { invaded }\end{array}$ & $\begin{array}{l}\text { Percentage } \\
\text { change in } \\
\text { d abundance }\end{array}$ \\
\hline \multicolumn{4}{|l|}{ Perennial grasses } \\
\hline Agropyron smithii & 61 & 163 & +89.0 \\
\hline Andropogon furcatus & 46 & 59 & $\begin{array}{r}1 \\
-\quad .4\end{array}$ \\
\hline Andropogon scoparius & 19 & 8 & -39.5 \\
\hline Bouteloua curtipendula & 49 & 92 & +223.0 \\
\hline Bouteloua gracilis & 12 & 19 & +328.3 \\
\hline Buchloe dactyloides & 1 & 7 & $\begin{array}{r}8 \\
+\quad 89.2\end{array}$ \\
\hline Carex spp. & 24 & 34 & $\begin{array}{r}+119.9 \\
\end{array}$ \\
\hline Koeleria cristata & 58 & 27 & -58.2 \\
\hline Panicum scribnerianum & 40 & 30 & $+\quad .6$ \\
\hline Panicum virgatum & 16 & 12 & -2.6 \\
\hline Panicum wilcoxianum & 28 & 5 & -93.0 \\
\hline Poa pratensis & 50 & 17 & -5.6 \\
\hline Sporobolus asper & 18 & 18 & +146.3 \\
\hline Sporobolus cryptandrus & 14 & 15 & +480.4 \\
\hline Sporobolus heterolepis & 10 & 9 & +11.1 \\
\hline Stipa spartea & 9 & 9 & -24.9 \\
\hline \multicolumn{4}{|l|}{ Perennial forbs } \\
\hline Amorpha canescens & 2 & 4 & +7.1 \\
\hline Aster multiflorus & 24 & 50 & -70.4 \\
\hline Artemisia gnaphalodes & 10 & 4 & -97.4 \\
\hline Callirrhoe alceoides & 5 & 3 & -53.6 \\
\hline Helianthus rigidus & 1 & 0 & -100.0 \\
\hline Liatris punctata & 3 & 3 & -72.9 \\
\hline Lithospermum linearifolium & 7 & 8 & $+\quad 3.4$ \\
\hline Oxalis stricta & 14 & 17 & +364.7 \\
\hline Solidago glaberrima & 22 & 11 & -95.3 \\
\hline \multicolumn{4}{|l|}{ Annuals } \\
\hline Bromus tectorum & 11 & 52 & +764.3 \\
\hline Chenopodium album & 1 & 2 & +170.0 \\
\hline Erigeron ramosus & 48 & 14 & -83.8 \\
\hline Festuca octoflora & 124 & 139 & -47.5 \\
\hline Hedeoma hispida & 8 & 35 & -50.9 \\
\hline Hordeum pusillum & 4 & 5 & +628.0 \\
\hline Lepidium virginicum & 25 & 11 & -89.6 \\
\hline Plantago purshii & 25 & 17 & -48.1 \\
\hline Salsola pestifer & 16 & 13 & $+1,800.0$ \\
\hline
\end{tabular}

ron smithii in the first three positions. In actual number of stems gained, Bouteloua gracilis, B. curtipendula, and Agropyron smithii stood first (figs. 2 and 3 ). Seven of the 16 most abundant perennial grasses had failed by 1939 to recover their losses of 1936. The most important of these were Andropogon scoparius, Koeleria cristata, and Stipa spartea. Although Poa pratensis disappeared from 33 plots and lost over one-half of its density after 1936, by 1939 it had recovered most of its losses. It was present in all but one of the prairies. 


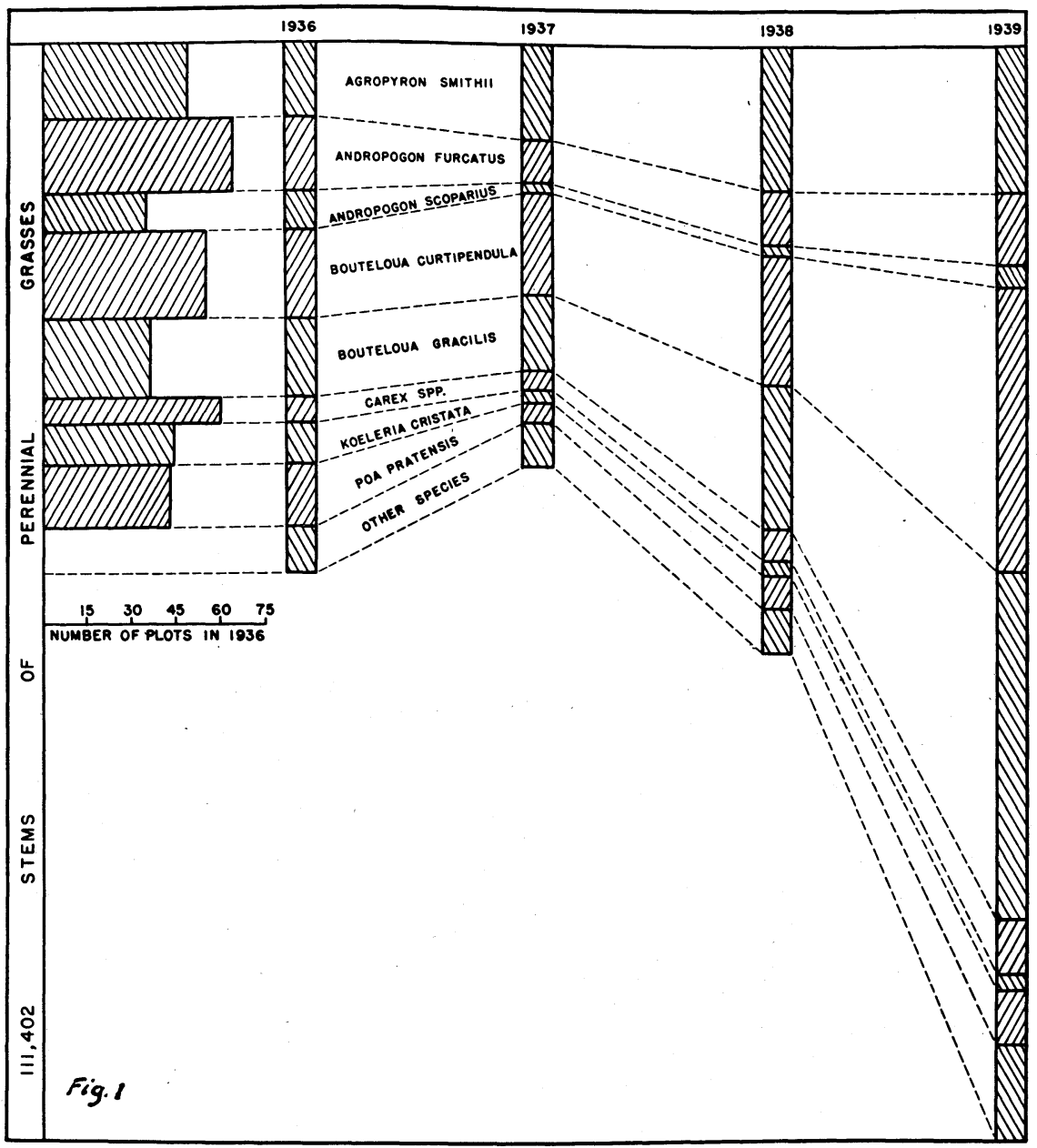

FIG. 1. Maximum number of stems of perennial grasses, number of plots in which each of the most important species occurred in 1936 (horizontal bars), and relative abundance in the plots (vertical columns) in 1936, 1937, 1938, and 1939.

If the total number of perennial grass stems be taken as 100 for 1936 , the values for the three subsequent years are 80, 114, and 205. No important species decreased its holdings on all of the prairies, and only two (Bouteloua gracilis and Sporobolus asper) made gains on all the prairies in which they occurred.

Perennial forbs were successively reduced to 72,53 , and 37 per cent of their 1936 abundance in 1937, 1938, and 1939, respectively (fig. 4). Aster multiflorus, Artemisia gnaphalodes, and Solidago glaberrima were among the most impor- tant species to sustain heavy losses. Oxalis stricta and Amorpha canescens were the only important forbs which made net gains. No species increased on every prairie, but by 1938 Achillea occidentalis had disappeared wherever sampled. Artemisia gnaphalodes, Helianthus rigidus, and Liatris punctata all but disappeared. Aster multiflorus, a perennial forb which increased greatly during the drought, had approached normal abundance in 1939.

Annuals as a group reached their maximum numbers in 1937. Spring rains 


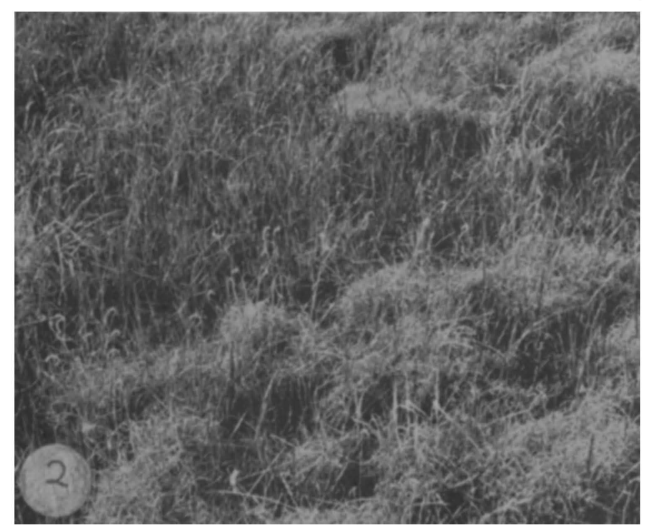

FIG. 2. Bouteloua gracilis (light color) spreading in Andropogon scoparius prairie. Photo. Lincoln, Nebr., April 29, 1939.

were adequate, the cover was open, perennial grasses were at their lowest ebb, and millions of seeds of all classes of annuals were present. Festuca octoflora, a native annual grass, was so abundant and increased so much that it was necessary to abandon the stem-count method and estimate its change by the number of square decimeter units of observation in which it was found each year. On that basis it increased from 1,700 to 2,800 and then to 3,200 square decimeters during the first three vears, the gain being

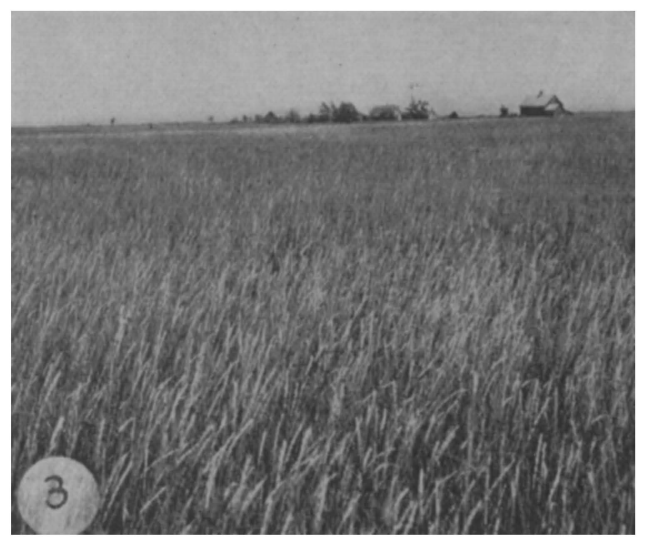

FIG. 3. Portion of a bluestem prairie at Carleton, Nebr., where the former grasses have been almost completely replaced since 1934 by western wheat grass. Note the paucity of forbs. Photo. June 15, 1938. uniform on the eight prairies where it occurred. In 1939, this annual lost on every prairie it occupied, and entirely disappeared from plots in the eastern stations. Bromus tectorum (and closely related species) was the only additional annual to become more abundant in 1938 than in the preceding year. Its gains were somewhat larger on the western prairies, where it invaded several sample plots. Coincident with the rapid increase in perennial grasses, annuals as a group decreased 33 per cent from 1937 to 1938 and 63 per cent from 1938 to 1939. Even so, they were in excess of normal abundance, and perennial native forbs were far below normal. The severe early drought of 1939 was doubtless a cause of the failure of annuals as well as the dwarfing of such early-growing, cooltemperature grasses as Koeleria cristata, Agropyron smithii, and Stipa spartea.

Of the four years, in 1938 only were seedlings of perennials common. The highest seedling counts were obtained for Bouteloua curtipendula, Panicum scribnerianum, $P$. wilcoxianum, Sporobolus asper, and Stipa spartea, in the order named. Only the third and last of these did not show the expected gains the following year. First year seedlings were not included in the census. Among perennial forbs, Amorpha canescens, Oxalis stricta, Aster multiflorus, and Callirrhoe alceoides had the most seedlings, but none of these survived the drought of the fall and winter.

These findings are in close agreement with those of more generalized surveys and various detailed measurements made annually in these prairies since the inception of the great drought in 1934.

\section{SUMMARY}

A study in nine widely spaced prairies in southeastern Nebraska and north-central Kansas was made by the list, or census, method over the period 1936 to 1939 , inclusive. Percentage change in abundance and relative stability of important 
FIG. 2. Bouteloua gracilis (light color) spreading in Andropogon scoparius prairie. Photo. Lincoln, Nebr., April 29, 1939.

were adequate, the cover was open, perennial grasses were at their lowest ebb, and millions of seeds of all classes of annuals were present. Festuca octoflora, a native annual grass, was so abundant and increased so much that it was necessary to abandon the stem-count method and estimate its change by the number of square decimeter units of observation in which it was found each year. On that basis it increased from 1,700 to 2,800 and then to 3,200 square decimeters during the first three vears, the gain being

FIG. 3. Portion of a bluestem prairie at Carleton, Nebr., where the former grasses have been almost completely replaced since 1934 by western wheat grass. Note the paucity of forbs. Photo. June 15, 1938. uniform on the eight prairies where it occurred. In 1939, this annual lost on every prairie it occupied, and entirely disappeared from plots in the eastern stations. Bromus tectorum (and closely related species) was the only additional annual to become more abundant in 1938 than in the preceding year. Its gains were somewhat larger on the western prairies, where it invaded several sample plots. Coincident with the rapid increase in perennial grasses, annuals as a group decreased 33 per cent from 1937 to 1938 and 63 per cent from 1938 to 1939 . Even so, they were in excess of normal abundance, and perennial native forbs were far below normal. The severe early drought of 1939 was doubtless a cause of the failure of annuals as well as the dwarfing of such early-growing, cooltemperature grasses as Koeleria cristata, Agropyron smithii, and Stipa spartea.

Of the four years, in 1938 only were seedlings of perennials common. The highest seedling counts were obtained for Bouteloua curtipendula, Panicum scribnerianum, $P$. wilcoxianum, Sporobolus asper, and Stipa spartea, in the order named. Only the third and last of these did not show the expected gains the following year. First year seedlings were not included in the census. Among perennial forbs, Amorpha canescens, Oxalis stricta, Aster multiflorus, and Callirrhoe alceoides had the most seedlings, but none of these survived the drought of the fall and winter.

These findings are in close agreement with those of more generalized surveys and various detailed measurements made annually in these prairies since the inception of the great drought in 1934.

\section{SUMMARY}

A study in nine widely spaced prairies in southeastern Nebraska and north-central Kansas was made by the list, or census, method over the period 1936 to 1939 , inclusive. - Percentage change in abundance and relative stability of important 


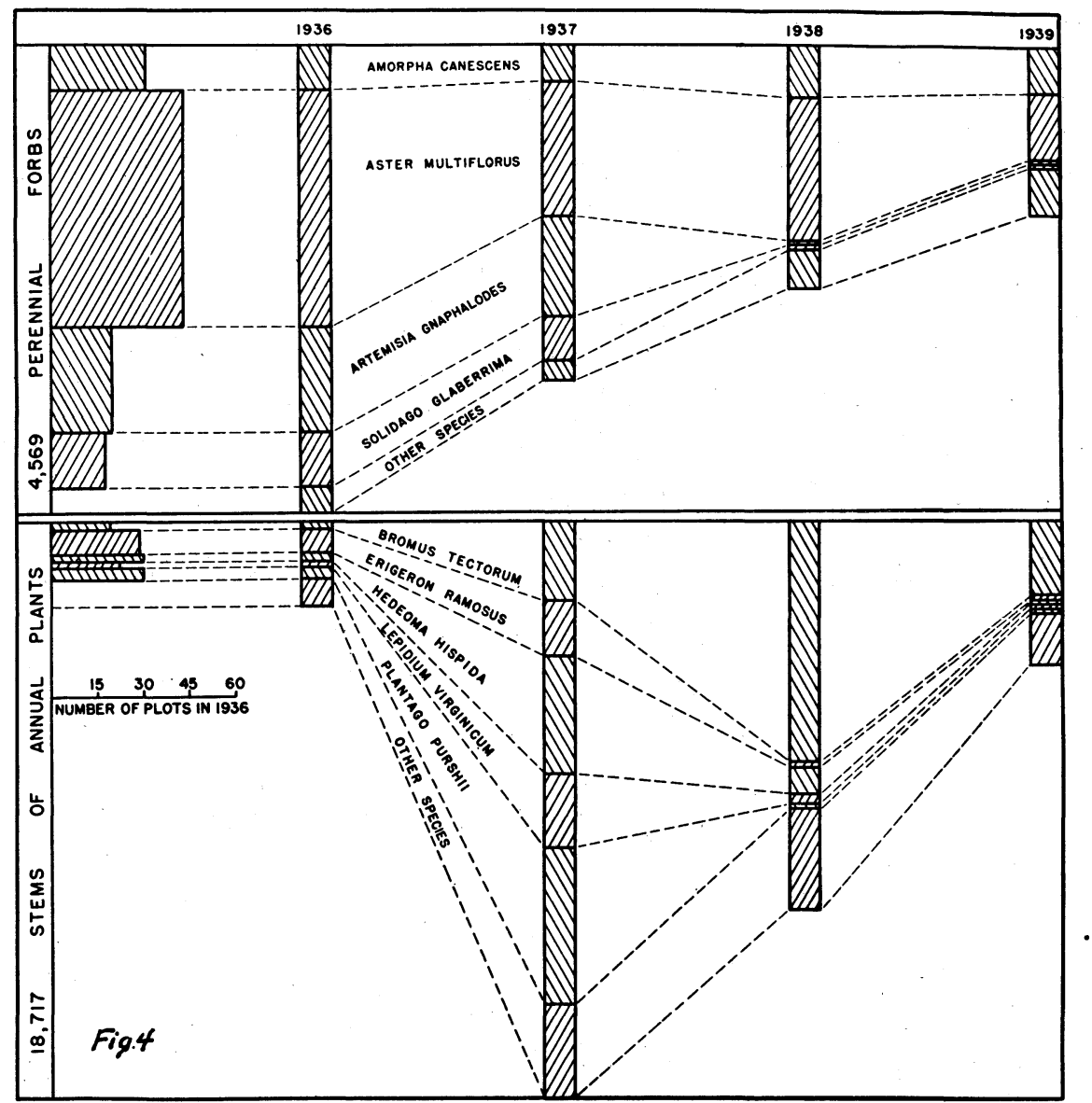

FIG. 4. Maximum number of stems of perennial forbs (upper section) and annual plants (lower section), number of plots in which the most important species occurred in 1936 (horizontal bars), and relative abundance in the plots (vertical columns) in 1936, 1937, 1938, and 1939.

species were calculated from data obtained from 75 plots. A decrease of 20 per cent in perennial grasses and 28 per cent in perennial forbs occurred following the severe drought of 1936.

Perennial forbs continued to decrease until 1939, when they were reduced to only 37 per cent of their 1936 abundance. The greatest losses were those of Aster multiflorus, Artemisia gnaphalodes, and Solidago glaberrima. Amorpha canescens and Oxalis stricta were the only important perennial forbs which made net gains.

Perennial grasses increased in abun- dance by 1939 to more than twice their abundance in 1936. Bouteloua gracilis, B. curtipendula, and Agropyron smithii, all xerophytic species, made gains of 328 , 223 , and 89 per cent, respectively.

Annual plants increased 564 per cent and attained their maximum numbers following the intense drought and great destruction of both perennial grasses and forbs in 1936. Bromus tectorum continued to increase until 1938, when it reached a high maximum. As a group, annuals decreased 33 per cent from 1937 to 1938 and 63 per cent from 1938 to 1939. 


\section{Literature Cited}

Kincer, J. B. 1934. The drought of 1934. Sci. Mo. 39: 95-96.

Nedrow, W. W. 1937. Studies on the ecology of roots. Ecology 18: 27-52.

Robertson, J. H. 1939. A quantitative study of true-prairie vegetation after three years of extreme drought. Ecol. Monog. 9: 431-492.

Stoddart, L. A. 1935. Osmotic pressure and water content of prairie plants. Plant Physiol. 10: 661-680.

Weaver, J. E., and F. W. Albertson. 1936.
Effects of the great drought on the prairies of Iowa, Nebraska, and Kansas. Ecology 17: 567-639.

Weaver, J. E., and F. W. Albertson. 1940. Deterioration of prairie from stability to denudation with decrease in soil moisture. Bot. Gaz. 101: 598-624.

Weaver, J. E., and T. J. Fitzpatrick. 1934. The prairie. Ecol. Monog. 4: 111-295.

Weaver, J. E., L. A. Stoddart, and W. Noll. 1935. Response of the prairie to the great drought of 1934. Ecology 16: 612629. 